Paedagogia Christiana

I/29 (2012) - ISSN 1505-6872

Marian Nowak ${ }^{*}$

Lublin

\title{
Czy szkoła ma przekazywać wiedzę, czy też wychowywać?
}

Artykuł chcę rozpocząć od podobnego jak w tytule, ale doprecyzowującego problematykę, pytania: Czy kryzysy, przemiany i ruchy religijne mogą rzutować na funkcjonowanie systemu edukacji szkolnej i w ogóle wpływać na rozumienie wychowania i nauczania? Chociaż zwykle tego rodzaju pytaniom nie przypisuje się większej uwagi we współczesnym świecie, to jednak, moim zdaniem, mogą one okazać się bardzo pomocne w zrozumieniu wielu sytuacji, z jakimi - także obecnie - mamy do czynienia w rzeczywistości szkolnej.

Na ogół w naszym kontekście kulturowym takie problemy uważa się za posiadające możliwe znaczenie jeszcze w przeszłości, ale nie obecnie, gdy zauważamy istotny wzrost możliwości i liczby kontaktów międzyludzkich, także tych z innymi kulturami i religiami oraz dążenia do funkcjonowania w rzeczywistości państwa czy społeczeństwa cywilnego ${ }^{1}$. Twierdzi się

* Ks. prof. dr hab. Marian Nowak - dyrektor Instytutu Pedagogiki Katolickiego Uniwersytetu Lubelskiego Jana Pawła II.

${ }^{1}$ Używam określenia „państwo/społeczeństwo cywilne” w sensie całkowicie świadomym, jako propozycję terminologii stosowanej zresztą w wielu językach świata i lepiej oddającej funkcjonowanie ludzkich społeczności, które chcą być rzeczywiście pluralistyczne i demokratyczne, aniżeli znane u nas i na przykład we Francji pojęcie „państwa laickiego”. Ponieważ „laicyzm” jest koncepcją „,wyznaniową” o określonej ideologii - w domyśle czytaj - ,ateistycznym" i to o nachyleniu przeważnie lewicowym, czy też pomysłem organizacji państwa światopoglądowo bardzo zdeterminowanego, warto poszukiwać zarówno modeli życia społecznego, jak i odzwierciedlających je kategorii, które potrafią zagwarantować konieczną niezależność od opcji ideologicznych czy światopoglądowych. Uważam, że takich warunków 
z wielu stron, że wszelkie tego rodzaju różnice - w czasach współczesnych będą się raczej niwelowały przy tych kontaktach (i ich skali), z jakimi mamy do czynienia chociażby w Europie. Faktycznie jednak nie dostrzega się, że właśnie te przemiany i wzrastająca liczba międzyludzkich kontaktów nie tylko może, ale w rzeczywistości wydaje się utrwalać istniejące podziały i rodzić prawdziwe zamieszanie koncepcyjne - jeśli nie będziemy podejmowali prób wyjaśnienia korzeni i podstaw obecnych podziałów.

Podstawowym problemem pracy szkoły jest nade wszystko dążenie do złączenia rzeczywistości obiektywnej i subiektywnej w ramach realizowanej pracy dydaktycznej i wychowawczej. Rozdzielanie tych dwóch zadań: wychowania od nauczania, łatwo może przeradzać się w dążenia na przykład do nadmiernej obiektywizacji przekazu kultury z pominięciem wartości osobowych, z pomijaniem roli woli i serca w integralnym rozwoju człowieka. Troska o integralny rozwój człowieka nakazuje wręcz i obliguje do uwzględnienia zarówno działalności dydaktycznej, jak i działań na rzecz wychowania do pracy szkoły i wszelkiego rodzaju aktywności podejmowanych w czasie szkolnych lekcji.

W tytule niniejszego artykułu pragnę najpierw przywołać sytuację, jaka zaistniała $\mathrm{w}$ okresie reformacji w Europie i, moim zdaniem, należałoby ją wiązać z faktycznym zaistnieniem wówczas dwu odmiennych koncepcji antropologicznych - jeśli chodzi o kwestię wolności człowieka, jej interpretowanie i jej znaczenie dla koncepcji wychowania: chodzi o ideę predestynacji w wielu odmianach protestantyzmu, która wyraźnie odbiega od stanowiska Kościoła katolickiego i Kościołów wschodnich w tym względzie. Jeśli zatem uwzględnimy cały kontekst chrześcijaństwa, w tym doktrynę niektórych odgałęzień protestanckich wspólnot, dążących do wierności idei predestynacji i utrzymywania się $\mathrm{w}$ tradycji nauczania o niej przez Jana Kalwina (1509-1564) czy Marcina Lutra (1483-1546), zaczynamy dostrzegać poważne rozbieżności w spojrzeniu na funkcje szkoły. Przyjęcie idei predestynacji nie tylko w przeszłości istotnie rzutowało - przynajmniej w pierwszym okresie reformacji - na rozumienie nie tylko nauczania, ale też na odrzucenie możliwości wywierania wychowawczego wpływu na postawy człowieka (wychowalność człowieka), lecz konsekwencje takiego nastawienia są obecne i dość ważne w podejmowanych edukacyjnych rozstrzygnięciach także współcześnie.

Wbrew powszechnym stereotypowym podejściom do nauczania i wychowania czy też do problematyki zadań i funkcji szkoły, wiązanym często z modelami pracy szkoły oraz uzależnianym od relacji podmiotów szkoły

nie spełnia też określenie „państwo obywatelskie” zawłaszczone przez ideologie o określonym nachyleniu światopoglądowym. W związku z tym postuluję kategorię „państwo cywilne”. 
(gdy mówimy między innymi o pajdocentryzmie i o magistrocentryzmie), w obecnym artykule chcę podjąć analizę zjawiska rysujących się różnic między funkcją przypisywaną nauczaniu i także wychowaniu w życiu człowieka. To właśnie wychodząc od podstaw antropologicznych i koncepcji człowieka, zauważamy odmienność między wspomnianymi Kościołami, mogącą istotnie wpływać na zadania stawiane szkołom i innym instytucjom wychowania i nauczania czy nawet resocjalizacji.

\section{Antropologiczne i historyczne podstawy koncepcji wychowawczych i dydaktycznych zadań szkoły}

Na rolę i zadania szkoły można patrzeć i je analizować w wielorakich perspektywach i sięgać do najbardziej odległej historii szkoły, jak chociażby do najczęściej wyprowadzanych początków szkoły - od tak zwanych szkót leśnych $\mathrm{w}$ społecznościach prymitywnych, następnie przez tradycję szkół w starożytnych kulturach, aż po historię wieków średnich i nowożytnych czy wreszcie współczesnych ${ }^{2}$.

Funkcjonowanie szkoły - jako instytucji nauczania i wychowania $\mathrm{w}$ istocie jest najczęściej wyrazem panujących w danej społeczności poglądów związanych z rozumieniem człowieka. Jest ono też wyrazem i odzwierciedleniem koncepcji człowieka i zapatrywań co do możliwości jego kształcenia i kształtowania. W tym sensie można analizować funkcjonowanie szkoły w poszczególnych cywilizacjach i epokach, a nawet w poszczególnych grupach społecznych. Byłoby to ważne i niewątpliwie bardzo potrzebne zadanie historyków szkolnictwa i edukacji szkolnej.

Moim zamierzeniem jest jednak odpowiedzieć na postawiony w tytułowym sformułowaniu artykułu problem w aktualnym kontekście europejskim. W tym właśnie kontekście, pomimo wielorakich podejść i koncepcji wychowania, możemy wyróżnić dwa podstawowe stanowiska oparte na zróżnicowanych antropologicznych założeniach, z których możemy wymienić:

1. Koncepcję wspierania wychowanka i ucznia w rozwijaniu jego potencjału. Jego rozwój jest priorytetem i podstawowym zadaniem zarówno indywidualnych wychowawców (a także własnych zabiegów wychowawczych), jak i oddziaływań zbiorowych na wychowanka. Wszystkie te działania, nie naruszając specyfiki, oryginalności i autonomii wychowanka, mają na celu zachowanie tych wartości i osobowej specyfiki wychowanka, broniąc go przed jakimkolwiek zewnętrznym wywieraniem nacisku bądź wpływem -

${ }^{2}$ Zob. m.in. A. Orczyk, Zarys historii szkolnictwa i myśli pedagogicznej, Warszawa 2008; G. Steindorf, Einführung in die Schulpädagogik, Bad Heilbrunn/Obb. 1976. 
dopuszczając najwyżej (jak to ma miejsce między innymi w antypedagogice) przekaz wiedzy, nauczanie czy informowanie.

2. Koncepcję oddziaływania na wychowanka w ramach adaptacji, socjalizacji i inkulturacji, przekazu wartości i uczynienia go członkiem społeczności, ukierunkowującą się na kształtowanie postawy wychowanka przez poszukiwanie adekwatnych i skutecznych sposobów takich oddziaływań. W tym wypadku wychowanek jest postrzegany jako materiał do obróbki zewnętrznej, do szkolenia i do ćwiczenia.

Przekładając te wskazania na postulowane koncepcje i zadania szkoły, możemy mówić w pierwszym przypadku o szkole opartej na koncepcji wolnościowej, realizującej jedynie nauczanie i przekaz wiadomości, w drugim zaś przypadku o szkole opartej na stosowaniu zewnętrznych oddziaływań, wpływaniu przez metody wychowania i nauczania na całą postawę człowieka i jego kształtowanie - w przekonaniu o wielkiej skuteczności i potrzebie tych oddziaływań.

Te przekonania stały u podłoża wielu stanowisk związanych z edukacją szkolną, wśród których zwłaszcza wskazuję na stanowiska postulujące jedynie nauczanie i przekaz wiadomości oraz na stanowiska wskazujące na potrzebę zarówno nauczania, jak i wychowywania w szkole.

W związku z pierwszą grupą stanowisk możemy wskazać między innymi na Jana Amosa Komeńskiego (Comenius, 1592-1670), który w swojej Didactica Magna, zwłaszcza w rozdziałach 13-19, odnosząc się do metod nauczania inspirujących się prawami natury i zasadami takimi jak przechodzenie od łatwych rzeczy do trudniejszych, od ogólnych do szczegółowych, od bliskich do dalszych, wypowiada jednocześnie swoistą walkę średniowiecznemu nauczaniu pojedynczych uczniów na rzecz umasowienia nauczania, co wiązało się także ze wzrostem znaczenia stosowania nagród i kar. Takie środki wychowawcze jak kary wynikały zresztą bardzo łatwo z postulowanej liczebności grup uczniowskich, nad którymi należałoby najpierw zapanować, aby dalej móc je nauczać.

Zalecając nauczanie całej dość liczebnej klasy, dużych zespołów uczniów w klasie szkolnej (Klassenunterricht) liczących do 100 uczniów, jednocześnie nauczanych przez jednego nauczyciela, który „tak jak słońce mógłby rozsiewać swoje promienie na wszystkich" (rozdział 19)3), Komeński eksponuje dydaktykę rozumianą jako ,sztuka nauczania wszystkiego wszystkich"4.

3 Zob. H. Gudjons, Pädagogisches Grundwissen. Überblick - Kompendium - Studienbuch, Bad Heilbrunn 1993, s. 72-74.

${ }^{4}$ A. Orczyk, dz. cyt., s. 111. 
Rola szkoły, która wyraźnie zaczyna się wyodrębniać w tej koncepcji, zaczyna być sprowadzana tylko do dydaktyki - owszem, aby nauczać „wszystkich i wszystkiego”, ale przecież tylko nauczać. I to wokół tylko tego zadania miałaby się koncentrować cała aktywność nauczyciela. Podstawę do takiego stwierdzenia dają nade wszystko słowa samego Jana Amosa Komeńskiego, który stawia przed nauczycielem bardzo wyraźne (chociaż zawężone tylko do dydaktyki) zadania:

Nauczyciel nie powinien się do nikogo szczególnie zbliżać, ani też pozwalać na to, aby ktokolwiek zbliżył się szczególnie do niego, lecz powinien pozostawać wysoko na katedrze (gdzie przez wszystkich mógłby być widziany i słyszany) i tak jak słońce rozsiewać swoje promienie na wszystkich. Wszyscy natomiast powinni ku niemu zwracać swoje oczy, uszy oraz wszelką uwagę i podejmować wszystko, co on przedkłada, pokazuje lub przypisuje ${ }^{5}$.

Bliżej analizując te stwierdzenia, dostrzegamy wyraźne przesunięcie się uwagi związanej ze szkołą jako instytucją wychowania i nauczania, z kształtowania postawy i wychowania na nauczanie i jedynie na przekaz wiedzy. O tym przesunięciu akcentu świadczy dobitnie sam tytuł dzieła Komeńskiego, akcentującego nauczanie i dyscyplinę nim się zajmującą - dydaktykę, a nie wychowanie i zajmującą się nim pedagogikę. Bliższymi przyczynami tego przesunięcia uwagi możemy uczynić przyjmowaną w kręgu także „braci czeskich" (w których religijnej wspólnocie Komeński pełnił funkcję biskupa) - doktrynę o predestynacji, która nie przewidywała jakichkolwiek możliwości wpływania na człowieka i jego postawę (owocującą między innymi odrzuceniem sakramentologii i wszystkich sakramentów poza chrztem). Idea powyższa dopuszczała jedynie możliwość wiedzy i nauczania. Słowa Komeńskiego z 14 rozdziału jego dzieła Didactica Magna, że pod względem swojego istnienia uczeń wszystko już ma i nie musimy go niczym obdarzać, ani niczego mu dodawać, wydają się taki stan rzeczy potwierdzać w całej rozciągłości. W Wielkiej Dydaktyce nie brakuje też słów polemiki i kontestowania przez Komeńskiego średniowiecznego modelu zindywidualizowanego nauczania, jakiego obecność zauważał Komeński także w tradycji Akademii Krakowskiej.

Natomiast postulowana przez Komeńskiego szkoła grupująca w swoich pomieszczeniach w jednej sali nawet powyżej 100-osobowe grupy uczniów, ani nie stwarzała, ani nawet nie zakładała możliwości jakiegokolwiek wychowania. Od tego też właściwie momentu możemy mówić o dwu wyraźnie

5 J. A. Comenius, Große Didaktik (1657). Übersetzt und herausgegeben von A. Flitner, Düsseldorf und München 1966, s. 123. 
precyzujących się i odróżniających w tradycji europejskiej modeli podejścia do kwestii kształcenia i stawiania szkole określonych zadań, które możemy ująć jako:

1) nauczanie jest podstawowym i jedynym zadaniem szkoły oraz

2) zarówno nauczanie, jak i wychowanie stanowią podstawowe zadanie szkoły.

Każde z tych podejść należałoby bliżej scharakteryzować.

\section{Stanowiska w kwestii zadań i funkcji szkoły}

Wielorakość zadań szkoły pozwala nam i stwarza możliwość wybrania i wyodrębnienia dwu podstawowych z nich, a mianowicie: zadanie nauczania i informowania oraz zadanie wychowania i nauczania, czy też kształcenia jednocześnie.

\subsection{Zadanie nauczania jako podstawowa funkcja szkoły}

W odniesieniu do pierwszego zadania szkoły - nauczania i informowania - widzianych jako podstawowe i centralne zadanie szkoły, w którym przekaz wiedzy wiąże się z przekazem informacji a zarazem wprowadzeniem w umiejętność czytania, pisania i rachunków, wprowadzenia w podstawowe obszary wiedzy lub mowy. Informowanie polega na otwieraniu człowieka na świat $\mathrm{w}$ jego poszczególnych obszarach i aspektach. Natomiast wielość aspektów i obszarów nauczania w szkole, mogąca powodować istotny chaos w percepcji, sprawia, że trudno sobie wyobrazić pracę szkoły bez planu i programu. Przekaz wiedzy, nauczanie i informowanie posiada i stawia przed nami szereg wymagań, na które powinniśmy odpowiadać właśnie przez uporządkowaną edukację szkolną ${ }^{6}$.

Nauczanie i informowanie wiąże się ze zdobywaniem wiedzy czy nawet określonych rodzajów wiedzy (wiedzy praktycznej, wiedzy empirycznej, teoretycznej, ideowej), a także pośredniczeniem w nabywaniu duchowych sprawności czy umiejętności. Nauczanie może koncentrować się na poszczególnych rodzajach wiedzy lub sprawności, ale też uczestniczyć w ich przekazywaniu. Nie brakuje też prognoz, że w związku ze współczesnym rozwojem mediów elektronicznych do przekazu wiedzy i informowania jako

${ }^{6}$ G. Geißler, Die Situation der Schule in der Gegenwart, w: H. Röhrs (Hrsg.), Theorie der Schule, Frankfurt/M. 1968, s. 172; G. Steindorf, dz. cyt., s. 59-60. 
dotychczasowego zadania szkoły dojdzie nade wszystko porządkowanie i uczenie organizowania oraz opracowywania otrzymywanych informacji. Prowadzenie uczniów do opracowywania szczegółowych aspektów i włączania ich w pewne ogólniejsze zbiory bądź bardziej uniwersalne kategorie, a także pogłębianie horyzontów myślowych młodego człowieka oraz wspieranie go w osiąganiu wyższych poziomów abstrakcji, stanowią podstawowy zestaw oczekiwań pod adresem współczesnej szkoły.

W tych oczekiwaniach tkwi zarazem podstawowe zagrożenie związane ze szkołą, a mianowicie, że szkoła w wysokim stopniu zadowala się nominalnym posiadaniem rzeczy i zjawisk, które nazywa, charakteryzuje, ale ciągle pozostaje w werbalnym wymiarze ich istnienia. Dlatego też szczególnego znaczenia nabiera w szkole ukierunkowanie i wyposażenie ucznia na przyszłość. Wiąże się to z przygotowywaniem ucznia do przyszłych zadań i obowiązków oczekujących go w dalszym życiu zawodowym, a do których szkoła powinna go wyposażyć ${ }^{7}$.

Nie bez znaczenia i zauważenia powinno być w tym względzie także zadanie szkoły związane $\mathrm{z}$ dostarczeniem informacji i wyjaśnieniem wyzwań losu oraz egzystencjalnymi problemami codzienności, w czym na szczególną uwagę zasługuje wiązanie ucznia z wiedzą ideową i wpisywanie w określony także światopogląd, co często ze swoistej konieczności przywołuje wymiar wychowawczy, a zarazem ukazuje niewystarczalność nauczania i informowania jako podstawowych zadań szkoły ${ }^{8}$.

\subsection{Zadanie wychowania i nauczania jako istota funkcjonowania szkoły}

Szkoła nie jest zatem i nie może być instytucją jedynie nauczającą, lecz jest ona także instytucją wychowania, stając obok rodziny jako jedna $\mathrm{z}$ istotnych instytucji wychowania młodego człowieka. Z pracą szkoły wiąże się zwłaszcza wychowanie do życia w społeczeństwie oraz otwarcie na wspólnotowe formy życia, a podkreślając jej rolę i zadanie socjalizacyjne zwłaszcza w zakresie socjalizacji wtórnej i związanej z nią pierwszej i orientacyjnej także socjalizacji zawodowej - nie można pominąć zadań adaptacji i animacji kulturowej oraz wkładu w rozwijanie osobowości wychowanka $(\text { personalizację) })^{9}$.

7 Zob. C. Schietzel, Betrachtung nach einem längeren Weg, "Westermanns Pädagogische Beiträge" 1969, s. 114-117.

${ }^{8}$ Zob. G. Steindorf, dz. cyt., s. 60.

9 Zob. H. H. Becker, Über Wesen und Gliederung wissenschaftlicher Pädagogik, Ratingen 1964, s. 52; także G. Steindorf, dz. cyt., s. 60-61. 
W złożonym procesie wychowania w szkole i przez szkołę możemy wyodrębnić szereg specyficznych oddziaływań związanych z jej rolą wprowadzenia uczniów w życie i jego złożoność, w świat przeżyć i emocji, w świat kultury, polityki i religii. Nade wszystko te zadania wychowawcze szkoła wypełnia przez realizowane według programu lekcje szkolne. Lekcje te oddziałują wychowawczo zwłaszcza przez swoje treści, przez ich etyczną i religijną zawartość-treść, w związku z czym mówił też J. F. Herbart o lekcji wychowujacej (erziehende Unterricht) - lekcje szkolne zawsze oddziałują, nawet jeśli są to na przykłąd lekcje z nauk przyrodniczych, wychowując także do precyzji i konkretnego myślenia. Regularność i cykliczność lekcji ułożonych i realizowanych w rytmie tygodni i kolejnych lat nauki wychowuje do pracowitości, systematyczności, pilności, punktualności itd. Ważnym środkiem wychowawczym lekcji szkolnych jest też wymaganie przez nie określonej pracy od uczniów, przez co lekcja wychowuje do przyszłych zadań zawodowych, ucząc - i to już na etapie edukacji szkolnej - zdolności do poświęcenia, przezwyciężenia wygodnictwa i lenistwa, a także zdolności koncentracji na zadaniu ${ }^{10}$. Szkoła może być postrzegana także jako miejsce spotkania, dialogu i relacji międzyosobowych (między nauczycielem-wychowawcą a uczniem-wychowankiem oraz innymi uczniami) ${ }^{11}$.

Nie bez znaczenia pozostaje także osobisty wpływ nauczyciela, który przez swoją postawę, kompetencję, zawodową pracę i podejście do niej, staje się najbardziej istotnym czynnikiem wychowania i wywierania wpływu wychowawczego. W tym względzie za Friedrichem Schneiderem (18811965) możemy stwierdzić, że

czy nauczyciel chce tego, czy też nie chce, wychowuje - lub wykoślawia także jeśli nawet nie ma takiego zamiaru i chciałby po prostu tylko nauczać. A zatem nie tylko wychodząc od swojej osobowości, nauczyciel wywiera wychowawczy wpływ na swojego ucznia, lecz czyni to także przez treści przekazywane w ramach swojego nauczania i przez stosowane metody ${ }^{12}$.

Warto też dodać, że obok wspomnianego potencjału wychowawczego, jaki jest zawarty w instytucji szkolnej, istnieje też tak zwane wychowanie szkolne, na które wskazywali między innymi pierwsi profesorowie Akademii Krakowskiej, a także w czasach bliższych naszym, między innymi Jan

10 Zob. A. Burkert, Erziehung. Theorie und Praxis in evangelischer Sicht, München 1963, s. 124; H. Henz, Lehrbuch der systematischen Pädagogik, Freiburg-Basel-Wien 1964, s. 187.

${ }_{11}$ Zob. G. Steindorf, dz. cyt., s. 61.

${ }^{12}$ F. Schneider, Einführung in die Erziehungswissenschaft, Graz 1948, s. 226. 
Henryk Pestalozzi (1746-1827), który stawiał szkole wyraźne zadanie wychowania i rozumiał je jako odpowiedź na potrzeby indywidualne i społeczne. Właśnie w czasach współczesnych, gdy zauważamy poważne osłabienie funkcji wychowawczej rodziny, zadania wychowawcze szkoły nabierają szczególnego znaczenia. Wydaje się, że szkoła wraz z wiekiem XX zaczęła przejmować zadania opiekuńcze - związane z funkcją opiekuńczą szkoły, którą władze oświatowe zleciły szkołom i instytucjom edukacyjnym w Polsce w 1933 roku, ale także w ostatnim okresie - zadania także prewencyjne i pielęgnacyjne, które jeszcze kilkanaście lat temu były całkowicie przypisywane do obowiązków i związane z rodziną ${ }^{13}$.

Nowym, ale coraz wyraziściej stawianym przed szkolną edukacją zadaniem staje się motywowanie i wzbudzanie zainteresowań w uczniach oraz rozwijanie kreatywności. Wywołane i obudzone w uczniu zainteresowania stają się ustawicznym zadaniem i obiektem troski wychowawczej nauczyciela i instytucji szkolnej ${ }^{14}$. Tę troskę w ostatnich latach określa się jako wychowanie do kreatywności, mającej wspierać innowacyjne i twórcze podejście do problemów życia, które same w sobie nie poddają się stereotypowości i szablonowości, lecz wymagają podejścia twórczego w ich rozwiązywaniu ${ }^{15}$.

Jeszcze innym zadaniem szkoły współczesnej jest emancypowanie wychowanka. Przez tę kategorię rozumie się wyzwolenie wychowanka $\mathrm{z}$ tego wszystkiego, co go ogranicza i wiąże wewnętrznie lub zewnętrznie i przeszkadza w podejmowaniu swoich własnych decyzji. Jest to w istocie wychowanie do krytycznej dojrzałości. Najtrafniej chyba ten właśnie aspekt wychowania ujętego jako emancypacyjne zadanie szkoły zdołał wyrazić Jan Paweł II w swoim przemówieniu do społeczności Katolickiego Uniwersytetu Lubelskiego w Częstochowie w czerwcu 1979 roku, gdy stwierdzał:

Uniwersytet wtedy spełnia swój własny cel, gdy w określonej wspólnocie ludzi, przy pomocy środków o charakterze naukowo-twórczym, naukowo-badawczym prowadzi do tego, że się rozwija człowiek, że się wyzwala jego wszechstronny potencjał duchowy. Potencjał umysłu, woli i serca; formacja całego

${ }^{13}$ Bliższemu naświetleniu tego faktu może posłużyć publikacja mojego autorstwa: M. Nowak, Pedagogiczny profil nauk o wychowaniu. Studium z odniesieniami do pedagogiki pielęgniarstwa, Lublin 2012; zob. także H. Heckel, P. Seipp, Schulrechtskunde, Neuwied $1965^{3}$, s. 6-7.

${ }_{14}$ Zob. H. Roth, Revolution der Schule? Die Lernprozesse ändern, Hannover 1969, s. 70 .

${ }^{15}$ Zob. H. R. Lückert (Hrsg.), Begabungsforschung und Bildungsförderung als Gegenwartsaufgabe, München-Basel 1969, s. 141; zob. także G. Steindorf, dz. cyt., s. 64. 
człowieka. [...] chodzi o to, czy się wyzwoliło ten olbrzymi potencjał duchowy człowieka, przez który człowiek urzeczywistnia swoje człowieczeństwo ${ }^{16}$.

Jeszcze inne zadania wychowawcze szkoły to między innymi wychowanie do pokoju z wykluczeniem agresji, przemocy i form siłowych rozwiązywania konfliktów międzyludzkich oraz podejmowaniem odpowiedzialności za przyszłość świata i własnej społeczności. Z tym wychowaniem wiąże się także wychowanie proekologiczne, wychowanie do ruchu drogowego, do wolontariatu itp.

\section{Ku efektywnej realizacji wychowawczych zadań szkoły wspólczesnej}

Jedną z podstawowych kwestii, związanych z wypełnianiem przez współczesną szkołę zadania wychowania i nauczania, wydaje się być konieczność znalezienia odpowiednich sposobów i dróg realizowania tak złożonego i wielorakiego procesu, jakim jest właśnie samo wychowanie i nauczanie. Wydaje się jednak, że brak gruntownych analiz nad istniejącymi i faworyzowanymi koncepcjami szkoły odbija się dość powszechnym chaosem i niespójnością nie tylko konkretnych działań instytucji szkolnych, ale nawet już samym kształceniem nauczycieli, czego świadectwem wydaje się być koncepcja kształcenia nauczycieli, czy też tak zwanego pedagogicznego przygotowania do wypełniania zawodu nauczycielskiego w szkole. Zarówno wcześniejsze rozporządzenia, jak i to ze stycznia 2012 roku wyraźnie odznaczają się jednostronnym rozumieniem zadań szkoły, związanych z informowaniem i nauczaniem oraz przygotowywaniem nauczycieli do wypełniania tylko tych zadań.

Jak zatem mogłaby współczesna szkoła ponownie wrócić do wypełniania swoich zadań nie tylko dydaktycznych, ale i wychowawczych?

Niniejszy artykuł stawia sobie za cel nie tyle instruowanie w zakresie problemu: Jak takie wychowanie w szkole realizować?, lecz o wiele bardziej, odwołując się do wcześniejszych analiz, jak również przytaczając konkretne przykłady takich lekcji i zajęć szkolnych, zamierza on wskazać na niektóre impulsy do podjęcia koniecznego w polskim szkolnictwie zwrotu, wymagającego także jasności co do wyznawanej i przyjmowanej koncepcji człowieka i związanej z nią koncepcji pracy szkoły.

16 Jan Paweł II, Pielgrzymki do Ojczyzny. Przemówienia, homilie, Kraków 2005, s. 129 -130 . 
W historii myśli pedagogicznej $\mathrm{w}$ związku $\mathrm{z}$ rolą wychowania i nauczania w szkole możemy odwołać się do trzech stanowisk spotykanych u teoretyków wychowania, a mianowicie: 1) Jana Fryderyka Herbarta (1776-1841) - tak zwane stanowisko jednotorowości; 2) Ottona Willmanna (1839-1920) - stanowisko tak zwanej dwutorowości oraz 3) Georga (Jerzego) Kerschensteinera (1854-1932) - stanowisko określane jako model krzyżowania się obu rodzajów działalności w szkole. Możemy przedstawić bliższą charakterystykę tych stanowisk w podanej wyżej kolejności.

Ad. 1. Herbartowska koncepcja lekcji wychowujacej to zarazem model takiej relacji między nauczaniem i wychowaniem w szkole, w którym ma miejsce ścisła więź między wychowaniem oraz nauczaniem i w której oba rodzaje działalności w szkole zespalają się aż tak bardzo, że dla autora tej koncepcji nie istnieje nauczanie bez wychowania, podobnie jak nie istnieje wychowanie, które nie byłoby nauczaniem. W tym sensie możemy mówić tutaj o stosunku jednotorowości między nauczaniem i wychowaniem. Zdaniem Herbarta, pedagogika, zajmująca się wychowaniem, jest nauką szerszą niż dydaktyka. Dydaktyka powinna służyć temu samemu celowi, jakiemu służy pedagogika, a tym celem jest kształcenie charakteru. Herbart przedstawia ideę „nauczania wychowującego", łączącego nauczanie i wychowanie. Oba rodzaje aktywności przebiegałyby po tym samym torze, a pojęcia nauczania i wychowania byłyby w szerokim sensie synonimiczne ${ }^{17}$.

Ad. 2. Otto Willmann natomiast uważał wychowanie i nauczanie za oddziaływania równorzędne i jednakowo ważne. Podobnie w relacji równorzędności ustawiał obie nauki: pedagogikę i dydaktykę, gdyż, jak stwierdzał, cele pedagogiki: wychowanie ogólne, kształcenie charakteru moralnego i woli, są równorzędne z celami dydaktyki: rozwijanie umysłu i przekazywanie kultury duchowej. Chociaż więc obie dyscypliny mają odrębne cele, to te cele są jednakowo ważne, zwłaszcza w pracy szkoły. Dlatego w szkole powinna panować swoista dwutorowość, podyktowana stosunkiem celów wychowania i nauczania $^{18}$.

Ad. 3. Wreszcie G. Kerschensteiner w Teorii ksztatcenia ${ }^{19}$ wskazuje wprawdzie na odmienność nauczania i wychowania, ale też na potrzebę ich wzajemnego krzyżowania się, zwłaszcza w pracy szkoły, gdyż mają one wspólny cel - kształcenie osobowości człowieka. Nauczanie i wychowanie przeplatałyby się zatem wzajemnie i kierowały ku jednemu celowi.

${ }_{17}$ Zob. E. E. Geissler, Herbarts Lehre vom erziehenden Unterricht, Heidelberg 1972; N. Kluge, Einführung in die Systematische Pädagogik. Ansätze zu einer systematischen Betrachtungsweise der Allgemeinen Pädagogik, Darmstadt 1983, s. 14-22.

18 O. Willmann, Didaktik als Bildungslehre (1882/88), Wien 1957.

${ }^{19}$ G. Kerschensteiner, Theorie der Bildung, Leipzig $1926^{2}$. 
Jak wynika z powyższego przedstawienia, te trzy stanowiska uznają wychowanie za odrębne od nauczania, zarówno pod względem treściowym, jak i sposobu realizowania, ale jednocześnie zdają się wyraźnie poszukiwać ich wzajemnej relacji i na nią wskazują. Tą relacją jest kolejno: jednotorowość (Herbart), dwutorowość (Willmann) i krzyżowanie się (Kerschensteiner) ${ }^{20}$.

Echo tych analiz możemy dostrzegać również w polskim kontekście myśli pedagogicznej i w dydaktyce, na przykład w analizach Wincentego Okonia, według którego współczesna dydaktyka (czy teoria kształcenia) coraz bardziej oddala się od kształcenia wyłącznie intelektualnej strony osobowości i przekazywanie wiedzy wiąże z rozwojem całej osobowości człowie$\mathrm{ka}^{21}$. W tym sensie Józef Półturzycki zwraca uwagę na rozumienie kategorii kształcenie usiłującej oddawać oba rodzaje aktywności, a mianowicie, że „kształcenie to nauczanie i uczenie się wespół z wychowaniem towarzyszącym tym procesom"22.

Wraz z pojęciem kształcenia współwystępuje często kategoria wyksztatcenia, która dla K. Sośnickiego oznacza efekt przekształcania intelektualnej strony człowieka. Autor ten zakłada także możliwość szerszego rozumienia wykształcenia - jako pewnego stanu całej psychiki człowieka - stanu osiągniętego przez „związanie jego strony emocjonalnej, wolicjonalnej i jego działania ze stroną intelektualną"23.

Ksztatcenie zatem prowadzi do wykształcenia i odnosi się do całej osobowości człowieka. Podobnie jak wychowanie i samowychowanie (czy wychowanie i formacja), które ostatecznie można sprowadzić do wytwarzania zmian w człowieku i jego życiu biologicznym, społecznym, duchowym. Nie brakuje i w tym względzie dążenia do wypracowania konkretnych modeli teoretycznych, odzwierciedlających próby wiązania ze sobą działalności wychowawczej i dydaktycznej w pracy szkolnej.

Przywołać chcę w tym celu trzy koncepcje realizowania zadania wychowania i nauczania $\mathrm{w}$ szkole, $\mathrm{z}$ jakimi spotykamy się w historii myśli pedagogicznej, zwłaszcza znanej w Niemczech. Te koncepcje to:

1. Koncepcja lekcji wychowujacej (der erziehende Unterricht).

2. Koncepcja lekcji ksztatcacej (der bildende Unterricht).

3. Koncepcja życia szkolnego (das Schulleben) i życia lekcyjnego (Unterrichtsleben).

Będą one stanowiły kolejne punkty obecnego etapu realizacji artykułu.

20 S. Kunowski, Podstawowe wiadomości dydaktyki ogólnej, Lublin 1946, s. 8-9.

${ }^{21}$ Zob. W. Okoń, Wprowadzenie do dydaktyki ogólnej, Warszawa 1998, s. 57.

22 J. Półturzycki, Dydaktyka dla nauczycieli, Torun 1997, s. 26.

${ }^{23}$ K. Sośnicki, Dydaktyka ogólna, Wrocław 1959², s. 37; W. Okoń, dz. cyt., s. 57. 
Ad. 1. Koncepcja lekcji wychowujacej (der erziehende Unterricht) wskazuje na związki, jakie istnieją między wychowaniem a nauczaniem, które wyraźnie identyfikował już J. F. Herbart (1764-1841) - autor koncepcji „lekcji wychowującej”. W swojej Allgemeine Pädagogik zauważał Herbart: „nie może istnieć żadne pojęcie 'wychowania' bez nauczania; tak jak i odwrotnie, przynajmniej w obecnym moim piśmie nie uznaję żadnej lekcji, która nie wychowywałaby"24.

W 30 lat później wydanym Szkicu wykładów z pedagogiki (1835 ${ }^{25} \mathrm{Her}-$ bart stosuje już wyraźnie pojęcie „lekcji wychowującej”, przyczyniając się do rozumienia zadania lekcji szkolnej jako: moralnego ulepszania człowieka. Wychodząc od swojej teorii psychologicznej, Herbart rozumiał wychowanie jako relację, w której przez przekaz pewnego zakresu treści i idei etycznych dochodziłoby do przemiany nastawienia wychowanka. Wbrew ówczesnym poglądom panującym także $\mathrm{w}$ środowisku protestanckiego Uniwersytetu w Królewcu, Herbart podkreśla siłę, jaką posiadałyby myśli i ideały wskazujące na dobro i z nim związane, uważając je za zdolne inspirować ucznia do przetłumaczenia ich i zamieniania w dobre czyny.

Lekcja szkolna miałaby zatem polegać na przedstawianiu takiego właśnie zakresu myśli etycznych i wzniosłych idei, a następnie takim osadzaniu ich w duszy wychowanka, aby z wiedzy o nich rodziła się wola poprawnego działania moralnego. Tak oto, według Herbarta, z przyjmowanej wiedzy powstawałaby zdolność właściwego działania w sytuacjach życiowych.

Tego rodzaju kształtowanie myśli i idei moralnych w uczniach w czasie lekcji umożliwia „prawidłowa”, metodycznie ukształtowana struktura lekcji, która tak powinna opracowywać wrażenia i je łączyć w twierdzenia, aby z nich powstawało etycznie zabarwione chcenie (wola) odpowiednio regulowane w ramach „formalnych stopni lekcji”, poprzez które nauczyciel był instruowany o tym, jak nauczając może on wychowywać.

Koncepcja ta, aczkolwiek oparta na zdezaktualizowanej współcześnie teorii psychologicznej Herbarta, w szczególny sposób przyczyniła się do uwydatnienia wychowującego wymiaru nauczania, chociaż bardzo łatwo $\mathrm{w}$ praktyce przekształcała się $\mathrm{w}$ tak zwany herbartyzm znaczony troską o przekazywanie jak największych ilości treści i materiału z poszczególnych dyscyplin nauczania szkolnego, w rzeczywistości owocując „,szkołą pouczającą” czy też jedynie „nauczającą".

${ }_{24}$ J. F. Herbart, Allgemeine Pädagogik aus dem Zweck der Erziehung abgeleitet (1806), Bochum 1971, s. 3nn.

${ }^{25}$ Tenże, Umriss pädagogischer Vorlesungen, Besorgt von J. Esterhues, Paderborn 1963; zob. także Th. Dietrich, Unterrichtsbeispiele von Herbart bis zur Gegenwart, Bad Heilbrunn/ Obb. 1980, s. 10-12. 
Minęło kilka dziesięcioleci, zanim ta koncepcja doczekała się próby reformy, jaka była związana z tak zwanym Jena-Plan-Schule (Planem Jenajskim) i poglądami Pietera Petersena (1884-1952) wskazującego na relacje międzyludzkie, konieczne do uwzględnienia w lekcji wychowującej. Jego zdaniem, podobnie jak i koncepcji Planu jenajskiego, jeśli lekcja ma być wychowująca, powinna opierać się na konkretnej współpracy uczniów, nauczycieli i rodziców i powinna prowadzić do konkretnych doświadczeń w działaniu. Człowiek najbardziej się wychowuje przez działanie i doświadczenie konkretnych czynów ${ }^{26}$;

Ad. 2. Koncepcja lekcji kształcacej (der bildende Unterricht), wychodząc od przekazu kultury i introcepcji wartości kultury w procesie wychowania, wskazuje na potrzebę otwarcia się człowieka na wartości kultury i kształcenia rozumianego jako „zarówno nauczanie, jak i uczenie się oraz wychowanie" (J. Półturzycki). Jeśli tak rozumiana lekcja ksztatcaca miałaby być nie tylko przekazem wiedzy, ale także prowadzić do wiedzy o pewnych ideach i podstawowych ideałach w wychowaniu, powinna starać się te wartości, idee i ideały odkrywać i przedstawiać jako treść dla kształcenia. Wolfgang Klaki wskazuje w tym względzie na rolę tak zwanej „formacji kategorialnej" mającej tak otwierać człowieka na świat, tak wiązać podmiot z przedmiotem, aby w procesie formacji związanie podmiotu z przedmiotem zaowocowało nabyciem podstawowych kategorii, w tym także poglądów, doświadczeń i przeżyćc ${ }^{27}$.

Ad. 3. Koncepcja życia szkolnego (das Schulleben) i życia lekcyjnego (Unterrichtsleben) jest najmłodszym ze stosowanych modeli realizacji zadania wychowania i nauczania. Wiąże się ten model z postacią C. G. Scheiberta z połowy XIX wieku. Jego zdaniem szkoła powinna być nie tyle instytucją nauczającą, ale także miejscem wspólnego życia i działania o charakterze społecznym - życie szkolne, a jeszcze dokładniej - szkoła powinna być rzeczywistym życiem. Rozszerzenie tej koncepcji lekcji wiąże się także z Ruchem Reformy Pedagogicznej z początków XX wieku, w którym nie brakowało dążeń do ujmowania w tych kategoriach lekcji-jako życie lekcyj$n e$. W obu koncepcjach otoczono szczególnym zainteresowaniem aktywność uczniów - zwłaszcza tę związaną ze wspólnym wypełnianiem zadań. Chociaż tak szkoła, jak i lekcja nie mogą być w pełni życiem, to jednak powinny jak najbardziej się do niego zbliżać, co będzie możliwe przy roztrząsaniu w nich

${ }^{26}$ Zob. Th. Dietrich, Zeit- Und Grundfragen der Pädagogik, Bad Heilbrunn/Obb. 1990, s. 148-149; także M. Nowak, Podawanie wiedzy czy wychowanie - zadaniem szkoty, ,Roczniki Nauk Społecznych KUL” 2 (1993), s. 79-92.

${ }_{27}$ Zob. M. Nowak, Podawanie, s. 79-92. 
problemów wziętych z życia. Bezpośrednio wiąże się z tą koncepcją także postulat unikania zbytniej przesady, abstrakcyjności i moralizatorstwa.

Wyróżnia się dwa zakresy występowania życia szkolnego: 1) ten związany z samą lekcją - jako życie lekcyjne oraz 2) ten widziany jako życie szkolne, z akcentem na wszelkie wydarzenia związane z wycieczkami szkolnymi, imprezami okolicznościowymi i uroczystościami szkolnymi, kółkami zainteresowań, grupami sportowymi i muzycznymi, czy też zajęciami plastycznymi. Zarówno w pierwszym przypadku - lekcji (a zatem w skali bardziej mikro-) jak i w drugim przypadku całej szkoły (w skali bardziej makro-) chodziłoby o doświadczenie życia społecznego czy wspólnotowego, możliwe także w ramach odgrywania scen z życia lub sztuk teatralnych, inscenizowania i wczuwania się w sytuacje ludzi przeżywających różne osobiste doświadczenia natury psychicznej, społecznej, kulturowej, moralnej czy religijnej itd.

Koncepcja życia lekcyjnego i życia szkolnego jest propozycją nowej koncepcji lekcji i funkcjonowania szkoły, włączonej zwłaszcza w przestrzeń życia wspólnotowego uczniów i usiłującej budować więź między wychowaniem, lekcją i nauczaniem w niej a życiem. Opracowania podejmujące tę problematykę wskazują często też na szereg trudności związanych z taką koncepcją lekcji, jak chociażby częste zmiany nauczycieli w klasie, duża i ciągle rosnąca liczba przedmiotów i w ogóle podział na poszczególne przedmioty/dyscypliny często bardzo zróżnicowane w swoim charakterze i stylu pracy dydaktycznej, ciasne pomieszczenia, a przy tym ciągle funkcjonujące szkoły-giganty, zespoły szkół, szkoły zbiorcze - zwłaszcza gimnazjalne i licea-giganty stanowiące realną przeszkodę otwarcia się na wspólnotę i właściwego funkcjonowania w zespole uczniowskim o takim charakterze, jak też przeżywania czegokolwiek z życia w ramach lekcji szkolnych czy też przebywania w murach szkoły.

Tutaj szczególnie musi w tych celach i ku tym wartościom ukierunkowywać się lekcja szkolna i cały styl pracy szkoły podstawowej, poprzez kolejne etapy edukacji - aż do uczelni wyższych. Lekcja powinna ukazywać wzajemne powiązania, jakie mają miejsce w codziennym życiu, wskazywać na relacje poszczególnych elementów i części, aspektów i poziomów życia, prowadzić do spojrzenia na całość. Nie wystarczy jednak tylko nauczanie, gdyż muszą być włączone również przeżycia i gotowość do samoprzezwyciężenia siebie, aby otwierać się na innych - to zaś wypływa z ideałów i nie pochodzi jedynie od racjonalnych przekonań i sądów, lecz wymaga czegoś więcej.

Jak zauważa to Podstawa programowa zarówno poprzednia, jak i tak zwana Nowa Podstawa Programowa, podstawowym zadaniem szkoły jest 
ciągle nie tylko nauczanie, ale i wychowywanie uczniów, a oba zadania powinny być ujmowane w szkole równolegle.

Papież Benedykt XVI w roku 2008 analizując sytuację wychowania w diecezji rzymskiej, ale z ukierunkowaniem się na ogólny obraz stanu edukacji, wskazuje na potrzebę edukacji, którą określa jako konieczną, a nawet „pilną potrzebę wychowania”"28. W przywoływanym liście Papież zauważa błędne pojmowanie wychowania sprawiające, że wychowanie ogranicza się jedynie do przekazywania umiejętności lub zdolności działania, natomiast pragnienie szczęścia młodych pokoleń zamierza się zaspokajać przez rzeczy natury konsumpcyjnej. Zdaniem Papieża konieczna jest w tym względzie atmosfera bliskości i zaufania, jakich powinni doświadczać wychowankowie ze strony wychowawców. Zadaniem nauczycieli powinno być poza przekazywaniem wiedzy także ukazywanie, jak pokonywać zwłaszcza egoizm. W tym względzie zachodzi, zdaniem Papieża, potrzeba odpowiedzialności społecznej, obywatelskiej i religijnej wychowawcy za młodego człowieka, który też musi nauczyć się być odpowiedzialnym za to, co robi. Sercem tak rozumianego wychowania ,podobnie jak całego życia, może być jedynie niezawodna nadzieja" ${ }^{29}$.

Powyższe zajęcie stanowiska przez Papieża w sprawie współczesnych problemów edukacji szkolnej możemy również odczytywać jako swoistą kontynuację stanowiska Kościoła katolickiego w sprawie wychowania i nauczania oraz zadań szkoły, także w obecnych czasach. Te słowa możemy odczytywać również jako przejaw troski „by - jak przed laty pisał papież Pius XI w swojej Encyklice 'O chrześcijańskim wychowaniu dzieci i mtodzieży' - w tej tak doniosłej kwestii nie tylko ustrzec się błędów, lecz przy Bożej pomocy móc torować drogę do pomyślnych wyników"30. Ukazane w niniejszym artykule przykłady lekcji, uwzględniającej w pracy szkoły zarówno nauczanie, jak i wychowanie, mogą stanowić podpowiedź do twórczego rozwijania własnego modelu realizowania nie tylko nauczania, ale i wychowania w szkole i na lekcjach. Chociaż współczesne koncepcje i podejścia do tej problematyki nie są aż tak mocno wiązane jak niegdyś z teologicznymi i antropologicznymi przesłankami dotyczącymi koncepcji wychowania człowieka i możliwości wpływania na jego postawy, to jednak ich przypomnienie może być bardzo pomocne do zrozumienia wielu zauważalnych i współcześnie występujących preferencji w tym względzie.

${ }^{28}$ Benedykt XVI, List do diecezji rzymskiej o pilnej potrzebie wychowania, „L'Osservatore Romano" 4 (2008), s. 4.

29 Tamże, s. 5.

${ }^{30}$ Pius XI, Divini Illius Magistri, w: Rada Szkół Katolickich, Stużyć wzrastaniu w prawdzie i mitości. Wybór dokumentów Kościoła na temat szkoły katolickiej i wychowania, Kraków 2009, s. 45. 
Jeśli zatem otwieramy się na realistyczną koncepcję człowieka i za J. F. Herbartem przyjmujemy za podstawę pedagogiki kategorię ,wychowalności" i chcemy konkretnie nieść pomoc w rozwoju wychowanka, nie możemy - podobnie zresztą jak Herbart - utrzymywać, że może istnieć nauczanie bez wychowania. Zadaniem szkoły nie może być zatem tylko przekazywanie wiedzy, lecz również wychowanie. Współczesna szkoła powinna oba te zadania podjąć i najwyżej rozważać za każdym razem i przy każdym z momentów i faz rozwoju, na który z punktów ciężkości zwrócić większą uwagę i gdzie położyć punkt ciężkości, w zależności od wieku uczniów, stanu ich wychowania i stanu wiedzy, w zależności od ich wrażliwości i zainteresowań oraz odpowiedzialności w zakresie omawianych problemów.

\section{Is Conveying Knowledge the Only Task of the Contemporary School? (Summary)}

While analyzing the objectives of the contemporary school, the article concentrates on its two main goals: conveying knowledge as well as providing moral, social and cultural development. Reaching to the past - the period of Reformation and the idea of predestination, still present today in some Protestant factions - the author demonstrates how this idea affects not only the concept of man in Europe, but also the idea of education and the acceptance or rejection of the so-called "educational capability", on which J.F. Herbart, amongst others, based the possibility of building pedagogy as an autonomous discipline. The idea of predestination was accepted by J.A. Komeński (Comenius) and others, and it was characterized by giving importance and even possibility of merely conveying knowledge and resulted in restricting the role of school and lessons only to teaching. The acceptance of the category of educability and relative lack of determination in human education - free from the idea of predestination - evident, for instance, in the teaching and educational tradition of the Catholic Church and the Eastern Churches, resulted in not only the position of pedagogical realism, but also in the assignment of both educational and didactic objectives to school. The article points to the continuous influence of this theoretical and ideological foundation on undertaken decisions and existing models of the present day school education.

Based on anthropological and historic foundations of educational and didactic concepts in reference to main objectives of school, the article points to possible solutions for linking education and instruction, establishes consequences for contemporary models of school functioning, with the focus on teaching (didactic function), or on teaching and moral instruction (educational and didactic function), and then presents conceptual models of lessons and school functioning while taking into 
consideration both teaching and instruction: 1) the instructive lesson (J.F. Herbart); 2) the educational lesson (W. Klafki) and 3) the school life (C.G. Scheibert).

The indicated models can be helpful in implementing the recommendations of the Core Curriculum of Polish schools (both the previous and the new Core Curriculum), that draw attention to both teaching and instruction of students in Polish schools. As Pope Benedict XVI demonstrated in his Letter to the Roman diocese in 2008, both objectives can be the answer to "an urgent need of education", overcoming the wrong tendency of transferring to students only the skills or abilities to act, and quenching the young generations' thirst for happiness with things of consumer nature. Thus representing the view of the Catholic Church, once again and in accordance with the position of defending a human being as a person which is known from history, the Pope opposes the diminishing and restricting of the objectives of school and appeals for a more evident implementation of not only didactic but also educational function of the modern school. 